\title{
Penerapan Bimbingan Kelompok Berbasis Lalaran untuk Mengatasi Kecemasan terhadap Hafalan Santri Di Pondok Pesantren
}

\author{
Jamilatul Fadliyah*, Hernisawati Hernisawati \\ Institut Agama Islam Ma'arif NU (IAIMNU) Metro Lampung, \\ Indonesia \\ @jamilatulfadliyah03@gmail.com
}

Submitted:
2020-04-19
Revised:
2020-05-20
Accepted:
2020-05-22
Copyright holder:
O Fadliyah, J., \& Hernisawati, H. (2020).
This article is under:
CCC
How to cite:
Fadliyah, J., \& Hernisawati, H. (2020). Penerapan Bimbingan
Kelompok Berbasis Lalaran untuk Mengatasi Kecemasan terhadap
Hafalan Santri Di Pondok Pesantren. Bulletin of Counseling and
Psychotherapy, 2(1).
Published by:
Kuras Institute
Journal website:
https://journal.kurasinstitute.com/index.php/bocp
E-ISSN:
2656-1050

E-ISSN:

\begin{abstract}
Basically everyone has felt anxiety at a certain moment in his life. But if the anxiety experienced is very excessive and left alone without the direction of someone can be very detrimental to the individual. As for memorization, anxiety often arises experienced by students. The need for guidance to facilitate students in memorizing and can reduce the level of anxiety they experience. Therefore, the formation of the application of group-based guidance in order to reduce anxiety in memorizing students in boarding schools. From the results of normality test results Sig. obtained a probability value $>0.05$ then the results can be stated normal. From the test results Sig. Based on Mean of Sig. 0.058> 0.05 variance of the data resulting from the application of group-based guidance in the experimental class and the control class are homogeneous. Based on the results of the group statistics above we can find out from the data generated by the experimental class as many as 10 people have an average value of 152.70 and in the control class as many as 10 people have an average value of 124.00 that has been obtained by each class. Independent samples test output table test results of students learning we can know the value of Sig. (2-tailed) is 0,000. Based on the criteria in decision making $0,000<0.05$, then $\mathrm{Ho}$ is rejected and Ha is accepted. So that there is a significant influence in the application of groupbased guidance in overcoming anxiety over memorization of the Sabrowi C class of Roudlotut Tholibin Islamic Boarding School. KEYWORDS: anxiety; psychoeducational group; lalaran
\end{abstract}

\section{PENDAHULUAN}

Dari keseluruhan aktivitas yang dilakukan santri hanya dilakukan didalam ruang lingkup pondok pesantren. Pada masa segala aktivitas yang dilakukan santri banyak sekali tingkah laku yang brgejolak dalam kehidupan pribadi sosialnya. Dalam hal ini disebabkan karena akibat banyaknya perubahan yang dialami oleh remaja baik itu dari segi fisik ataupun psikis. Pada masa-masa seperti ini umumnya remaja atapun santri mencari identitas dirinya yang mana banyak sekali problem-problem yang dialami oleh santri di pondok pesantren. Dilihat dari hasil penelitian didalam keseharian santri secara intrapersonal meliputi masalah kurang percaya diri, tidak mampu secara akademik, dan sakit fisik. Dilihat dari segi interpersonal yaitu berbagai masalah dengan orang tua, ekonomi, dan sesama santri. Kecemasan yang sering dialami oleh santri adalah berbagai masalah konsep diri, dan kemampuan 
menyelesaikan masalah. Pastinya semua orang pernah mengalami sebuah kecemasan pada diri masing-masing yang dialami dari berbagai banyak faktor.

Melihat dari segi umumnya memamg pondok pesantren tidak terlepas dari berbagai hafalanhafalan yang diberikan oleh guru yang ada dipondok pesantren. Tidak semua santri mengalami kemudahan dalam segi menghafal. Dalam aktivitas santri dipondok pesantren seperti menyetor berbagai hafalan tergantung pada sikap kemandirian diri santri dan sikap disiplin masing-masing individu terhadap menghafal kitab yang diterapkan dalam sehari-hari (Masduki, 2018). Kecemasan yang dirasakan pada dasarnya belum tentu terjadi, dan rasa cemas yang sebenarnya yaitu rasa ketakutan yang diciptakannya sendiri. Suatu aktivitas pada konseli hampir seluruh hal yang dilakukannya dilakukan dengan rasa khawatir ataupun cemas dan rasa takut. Dari situlah konseli memiliki rasa tidak nyaman dan serba salah dalam melakukan segala aktivitas secara maksimal. Rasa tertekan, tuntutan didalam kondisi mental yang ada pada diri konseli itulah yang menyebabkan tidak tercapainya suatu tujuan. Ketika santri yang memiliki rasa cemas dan takut menjelang masa hafalan, justru akan sangat mengganggu kejernihan pikiran dan daya ingat untuk menghafal dengan cara efektif maka dari situlah kejernihan pikiran dalam menghadapi hafalan sangat dibutuhkan. Berdasarkan kondisi yang dialami oleh santri tersebut perlu dan wajib untuk mempersiapkan diri sebelum melakukan hafalan (Suardana \& Simarmata, 2013).

Problem yang dimiliki santri terhadap hafalan yang berbasis lalaran yang dilakukan secara kelompok dapat menghilangkan rasa cemas yang mendalam dan dapat memberikan dorongan ataupun motivasi pada diri santri untuk lebih semangat dan kompak dalam melakukan hafalan. Ekspresi yang nampak pada diri santri yaitu nampak ceria dalam melalar sebuah hafalan. Dengan melalar secara bersama-sama atau kelompok memiliki reaksi yang baik dibandingkan dengan cara individu. Namun kadang kala faktor lain diluar hafalan seperti konflik dengan teman sebaya, ekonomi, keluarga dapat mengganggu rasa semangat konseli karena terfokus berbagai arah dan dapat mengganggu konsentrasi santri dalam menghafal. Jadi, dari situlah dibutuhkannya ke-efektifan dalam menghafal dalam bimbingan kelompok dalam memberikan rasa sadar pada diri santri untuk lebih terfokuskan dalam menghafal. Sikap rendahnya kesadaran mengulang-ulang dalam menghafal pada diri santri dapat berdampak sulitnya menyetor berbagai hafalan-hafalan yang diberikan oleh guru. Demikian pula didalam diri santri memiliki rasa resah ataupun cemas dalam menyetor hafalan sedemikian mestinya.

Adapun sikap percaya diri pada santri itupun harus benar-benar ditanamkan yang mana pada dasarnya merupakan sebuah keyakinan untuk menjalankan kehidupan yang dialami terhadap sesama (Suhardita, 2011). Mampu mempertimbangkan pilihan dan membuat keputusan bahwa ia mampu untuk melakukan sesuatu. Yakin dan percaya diri bahwa saya mampu menghafal pada hafalan yang sudah ditetapkan didasari dengan usaha yang maksimal dari situ akan membuahi hasil yang memuaskan. Pada diri santripun harus bisa mengatur waktunya agar dapat konsentrasi dalam menghafal, ulet, dan tidak bosan untuk mengulang-ulang hafalan dengan cara dilalar ataupun sebagainya. Dalam kamus Bahasa Indonesia kata menghafal merupakan asal kata hafal yang memiliki arti telah masuk pembelajaran dalam ingatan atau dapat mengucapkan diluar kepala tanpa adanya melihat buku atau catatan lain. Lalu ditambah dengan awalan me- menjadi menghafal yang artinya suatu usaha yang dilakukan meresapkan kedalam pikiran agar selalu ingat. Dari kata menghafal dapat disebut juga memori. Yang mana apabila kita mempelajarinya maka membawa seseorang kedalam psikologi kognitif. Didalam metode menghafal merupakan suatu cara yang tepat dan cepat dalam melakukan suatu kegiatan belajar mengajar pada bidang pelajaran dengan menerapkan suatu hafalan. Adapun dilakukannya hafalan tersebut guna memiliki tujuan peserta didik agar mampu mengingat-ingat pelajaran yang telah diberikan dan diketahui serta dapat melatih daya kognisi, ingatan, dan imajenasi (Zainudin, 2016).

Menurut pendapat yang dikemukakan oleh Suryabrata, dalam istilah menghafal yakni mencamkan sesuatu. Suatu proses dengan cara dilakukannya dalam berkata atau melafalkan dengan 
rasa sadar dan diiringi dengan rasa sangat bersungguh-sungguh mencamkan sesuatu tersebut untuk memperoleh suatu pengetahuan. Menurut beliau yang dikemukakannya, hal-hal yang dapat membantu atau mempermudah dalam menghafal yaitu dengan cara menyuarakan dalam melakukan hafalan agar dalam menghafal berjalan dengan efektif, dapat membagi waktu dengan tepat guna menambah hafalan, menambah hafalan sedikit demi sedikit dan konsisten. Adapun metode-metode dalam menghafal yang dikemukakan oleh Sumardi Suryabrata pertama, dengan melakukan metode keseluruhan yaitu mengulang berkali-kali dari awal hingga akhir, kedua, metode bagian yaitu menghafal dengan cara bagian perbagian dalam kalimat yang dihafalkannya, ketiga, metode campuran, yaitu menghafal dengan dipilih bagian-bagin yang memang sangat sulit untuk dihafal lalu setelahnya dilakukan dengan cara menyeluruh.

Menghafal diartikan pula sebagai aktifitas penanaman materi verbal di dalam ingatan, sesuai dengan materi asli. Dengan demikian, menghafal dapat diartikan dengan memasukkan materi pelajaran kedalam ingatan sesuai dengan materi asli sehingga terjadinya kemampuan dalam mengucapkannya dengan mudah meskipun tanpa didasari dalam melihat tulisan atau lafalnya. Metode menghafal merupakan ciri umum dalam sistem pendidikan Islam di masa ini. Untuk dapat menghafal suatu pelajaran dengan mudah murid harus membaca berulang-ulang sehingga pelajaran dapat melekat di benak mereka. Sebagaimana kata Imam Hanafi bahwa seorang murid harus membaca suatu pelajarannya dan terus menerus mengulanginya sampai dia menghafalnya. Dalam proses selanjutnya, siswa akan mengeluarkan kembali dan mengkontekstualisasikan pelajaran yang di hafalnya sehingga dalam diskusi atau perdebatan dia dapat merespon, mematahkan lawan, atau memunculkan sesuatu yang baru.

Adapun lalaran disini merupakan suatu pembiasaan membaca dengan diberikannya lirik ataupun lagu yang dihafal. Ialaran merupakan metode dan teknik secara umum yang terdapat didalam prinsip-prinsip pembelajaran didalam lembaga pendidikan pesantren. Guna memudahkan hafalan, santri pada umumnya melakukan lalaran terlebih dahulu terhadap syair ataupun nadhom yang akan dihafalkannya. Melalui lalaran santri dengan sendirinya akan mudah hafal terhadap apa yang dibacanya secara berulang-ulang (Fitriyah dkk., 2019). Lalaran merupakan suatu metode pengulangan materi yang mana dilakukan oleh seorang santri secara mandiri ataupun dilakukan secara kelompok. Dari pengertian di atas dapat kita simpulkan bahwa hafalan berbasis lalaran yaitu suatu proses tingkah laku yang di lakukan secara sadar dengan melakukan proses pengingatan tanpa melihat di dalam pelajaran yang di lakukan secara berulang-ulang. Prosese hafalan berbasis lalaran dapat di lakukan dengan mengeluarkan suara disertai dengan cara memberikannya sebuah nada dalam pelajaran yang akan di hafal dengan cara berulang-ulang sehingga dapat dengan mudah untuk mengingat pelajaran yang telah dihafalkan.

\section{METODE}

Berdasarkan karakteristik masalah yang diteliti, penelitian ini dapat diklasifikasikan kedalam penelitian kuantitatif karena secara umum penelitian ini bertujuan untuk menggambarkan, memahami serta menjelaskan suatu pokok masalah yakni "Penerapan Bimbingan Kelompok Berbasis Lalaran untuk Mengatasi Kecemasan Terhadap Hafalan Santri di Pondok Pesantren Roudlotut Tholibin 28 Purwosari Metro Utara Kota Metro" metode penelitian ini dipengaruhi oleh model penelitian alam. Dalam penelitian menggunakan kuantitatif menuntut suatu kebenaran yang bersifat positif dan dapat diverifikasi dan karenanya harus dapat diindera ataupun terlihat oleh mata (Purwanto, 2013).

Dalam metode yang digunakan adalah desain survey yang bertujuan untuk mengumpulkan beberapa informasi tentang orang yang jumlahnya besar, dengan cara mewawancarai sejumlah kecil dari populasi atau dapat dikatakan sampel. Jumlah orang yang akan dijadikan sampel, taraf hingga mana sampel itu dapat mewakili kelompok yang sedang diselidiki, tingkat kepercayaan informasi yang diperoleh dari sampel itu sendiri. 
Membuat data yang dapat dipercaya, tidaklah muda. Sehingga tidak dapat memaksakan orang untuk dapat mengatakan yang benar dan sering terjadi pada diri santri. Oleh karena itu, untuk memperoleh keterangan dapat digunakn dengan observasi, wawancara, angket, metode tes dan dokumentasi.

Subjek yaitu suatu bagian dari populasi yang akan di teliti oleh peneliti. Maka dari itu sampel harus dilihat sebagai suatu pendugaan terhadap subjek dan bukan subjek itu sendiri, atau sebagian dari individu yang akan diteliti dari keseluruhan individu penelitian (Narbuko \& Achmadi, 2013). Subjek yang berupa contoh, yaitu sebagian dari seluruh individu yang akan dijadikan objek penelitian (Mardalis, 1995). Subjek adalah bagian dari jumlah dan karakteristik yang dimiliki oleh populasi tersebut (Sugiyono, 2000). Subjek dapat disimpulkan bahwa suatu contoh dari jumlah karakter yang dimiliki oleh populasi guna untuk mendapatkan keterangan dari suatu yang akan di teliti. Saya mengambil sampel dalam satu kelas sabrowi C yang terdiri dari 40 santri yang akan diteliti. Sebelum santri memberikan atau menyetor hafalan kepada guru atau ustdazah, disini terlebih dahulu peneliti memberikan pretest kepada santri. Dari pretest tersebut kita ambil penilaian dari santri 20 terendah dari 40 santri. Dari 20 santri terendah akan dibagi menjadi 2 kelompok yang terdiri dari 1 kelompoknya berjumlah 10 santri. 2 kelompok tesebut akan diberikan kelas kontrol dan eksperimen. Bentuk lalaran dalam menghafal ditentukan oleh masing-masing kelompok. Lalaran ini guna untuk mengurangi kecemasan dalam menghafal pada diri santri, yang mana dapat terciptanya keefektifan dalam menghafal di dalam kelas.

Teknik sampling ialah suatu teknik yang merupakan pengambilan sampel (Sugiyono, 2000). Teknik sampling purposive ini digunakan dengan menentukan kriteria khusus terhadap sampel. Dalam penelitian sampel yang diambil adalah kecemasan dalam menghafal. Dengan memberikan pretest dan posttest dan dikategorikan standarnya yang termasuk kategori baik dan kategori kurang baik. Kemudian di jadikan satu sesui dengan kategori yang telah di kategorikan.

Observasi sebagai teknik pengumpulan data mempunyai ciri yang spesifik bila dibandingkan dengan teknik yang lain. Teknik pengumpulan data dengan observasi digunakan peneliti berkenaan dengan prilaku manusia, proses kerja, gejala-gejala alam dan bila responden yang diamati tidak terlalu besar. Sutrisno Hadi mengemukakan pendapatnya bahwa, observasi adalah suatu proses yang tersusun dari berbagai proses biologis dan psikologis. Yang paling terpenting adalah pengamatan dan ingatan (Sugiyono, 2000). Dilakukannya observasi guna untuk mengamati perubahan tingkah laku santri sebelum dan sesudah dilakukannya bimbingan dan konseling (Ashari dkk., 2016). Observasi ini dilakukan dengan cara peneliti langsung datang kelokasi penelitian untuk mengamati secara langsung upaya yang dilakukan santri saat menghafal kitab diPondok Pesantren Roudlotut Tholibin.

Wawancara digunakan sebagai pedoman bertujuan untuk mengumpulkan data berkaitan dengan pelaksanaan layanan bimbingan kelompok diselenggarakan dipondok pesantren. Wawancara yang digunakan hanya berupa permasalahn yang akan ditanyakan. Wawancara disini dilakukan dengan cara bertatap muka terhadap yang bersangkutan dalam penelitian yang akan dilaksanakan di pondok pesantren. Wawancara disini akan dilakukan dengan menemui wali kelas sabrowi $\mathrm{C}$ secara langsung. Dengan cara melakukan percakapan dialog secara lisan dimana peneliti mengajukan beberapa pertanyaan kepada responden lalu responden juga menjawab secara lisan.

Angket digunakan dalam penelitian untuk dibagikan kepada santri-santri untuk mendapatkan sampel-sampel yang telah terpilih, lalu dari situlah angket tersebut akan diuji validasi dan reliabilitas. Metode angket merupakan serangkaian atau daftar pertanyaan yang disusun secara sistematis, kemudian dikirim untuk diisi oleh responden. Bentuk umum dari sebuah angket yaitu terdiri dari bagian pendahuluan berisi tentang petunjuk pengisian angket, terdapat bagian identitas yang berisi identitas responden atau yang bersangkutan seperti: nama, alamat, umur, pekerjaan, jenis kelamin, status pribadi dan sebagainya lalu baru memasuki bagian isi angket (Bungin, 2005). Angket ini akan dibagikan pada santri kelas sabrowi $\mathrm{C}$ di Pondok Pesantren untuk mengetahui seberapa besar kecemasan yang di alami santri pada saat memberikan hafalan di Pondok Pesantren. 
Metode Tes disini dilakukan guna untuk mengetahui dari segi seberapa besar kemampuan santri dalam melakukan hafalan didalam kelas, yang mana santri itu sendiri dapat mengurangi rasa kecemasan dalam menghafal. Setelah santri melalar kitab yang telah di tentukan masing-masing santri, disini dipanggil satu-persatu untuk maju kedepan guna untuk memberikan hafalan yang telah mereka hafalkan. Lalu peneliti akan memberikan posttest berupa angket kepada santri diruang kelas. Dari sini kita dapat mengetahui seberapa besar kecemasan yang dialami oleh santri ketika memberikan hafalan terhadap guru pada kelas sabrowi C Pondok Pesantren.

Dokumentasi dilakuakn guna mengumpulkan data yang berdasarkan dokumen mengenai keefektifan bimbingan kelompok atau suatu peristiwa-pristiwa yang terjadi dan dilakukan pencatatan penting, buku, notulen, agenda, surat kabar dan lain sebaginya. Dokumentasi ini dilakukan pada santri kelas sabrowi C Pondok Pesantren Roudlotut Tholibin.

Agar tidak terjadi kesalahan dalam pengukuran data, maka alat ukur harus dimiliki tingkat validitas dan reabilitas yang tinggi, uji validitas alat ukur adalah "alat ukur yang berfungsi dengan baik itu akan mengukur dengan tepat mengenai gejala sosial tertentu, baru kemudian alat ukur tersebut menunjukkan kevalidan atau kelebihan suatu instrument. Pengujian validitas dengan menggunakan kriteria penilaian diterima dan tidaknya penilaian. Dalam penilaian ini dengan menggunakan bantuan program SPSS (statistical package for the social secinces).

Menurut Arikunto dalam pendapatnya reabilitas menunjukkan pada suatu pengertian bahwa suatu instrument cukup dapat dipercaya untuk dipergunakan sebagai alat pengumpul data karena instrument tersebut sudah baik. Untuk menguji reabilitas instrument menggunakan SPSS 16.0 sebagai alat uji reabilitas untuk mengukur keabsahan data (Astuti, 2018).

Dengan menggunakan instrument yang sudah valid dan reliabel dalam proses pengumpulan data. Maka yang diharapkan penelitian yang digunkan akan menjadi valid dan reliabel. Dengan data yang valid dan reliabel adalah salah satu syarat untuk dapat mendapatkkan hasil yang sangat mutlak.

Uji Validitas digunakan untuk mengetahui valid atau tidaknya butir-butir pertanyaan dalam membantu mendefinisikan suatu variabel. Daftar pertanyaan ini umumnya mendukung suatu kelompok variabel tertentu. Maka dari itu, peneliti menggunakan uji validitas karena peneliti menggunakan butir-butir pertanyaan dalam melakukan penelitian yang fungsinya sebagai instrumen penelitian. Uji validitas dalam penelitian ini menggunakan bantuan program SPSS 16.0. Jika $r$ nilai lebih besar dari corelation ( $r$ tabel) maka item nya valid sebaliknya, jika $r$ nilai lebih kecil dari corelation ( $r$ tabel) maka item tidak valid.

Angket tersebut akan dibagikan terhadap 40 santri yang ada didalam kelas yang akan diteliti. Dari hasil angket tersebut akan ditemukannya beberapa santri yang memiliki tingkat kecemasan dalam menghafal dikelas sabrowi $\mathrm{C}$ yang akan dijadikannya sebuah penelitian.

Reabilitas merupakan suatu alat ukur yang dapat dipercaya. Suatu hasil penelitian dapat dipercaya apabila telah dilakukannya pengukuran berkali-kali terhadap subyek yang sama maka hasil yang telah diperolehnya relatif sama. Selama dari beberapa aspek belum berubah.

Hasil yang telah didapat koefisen reliabilitas sebesar 0,724. Dari hasil tersebut nilainya lebih besar dari corelation ( $r$ tabel) maka dapat dinyatakan item nya valid dan dapat digunakan sebagai penelitian.

\section{HASIL DAN PEMBAHASAN}

Adapun uji tes normality yaitu sebagai hasil uji yang memiliki kenormalitasan terhadap data yang telah diperoleh. Dari nilai Sig. Atau signifikasi atau nilai probabilitas $<0,05$ maka di nyatakan hasilnya tidak normal, sedangkan apabila diperoleh nilai probabilitas $>0,05$ maka dapat dinyatakan hasilnya normal. Dari hasil tes normality tersebut dapat kita lihat dari nilai Sig. atau signifikasi atau nilai probabilitas memiliki hasil nilai normal.

Dari hasil uji test of homogeneity of variance tersebut dapat kita lihat pada nilai Sig. Based on Mean untuk variabel hasil keefektifan bimbingan kelompok berbasis lalaran untuk mengatasi 
kecemasam dalam menghafal kelas sabrowi $\mathrm{C}$ adalah sebesar 0,058. karena nilai pada Sig. 0,058 > 0,05 maka dapat kita ambil kesimpulan bahwa varians data hasil keefektifan bimbingan kelompok berbasis lalaran pada kelas eksperimen dan kelas control adalah homogen.

\begin{tabular}{lll}
\multicolumn{2}{l}{ Tabel 2. Hasil Uji Wilcoxon } \\
\hline Pengukuran & & Value \\
\hline Kontrol & M & 124.00 \\
& SD & 11.225 \\
Eksperimen & M & 152.70 \\
& SD & 7.181 \\
& t & 6.811 \\
& $\mathrm{P}$ & $<.05$ \\
\hline
\end{tabular}

Berdasarkan hasil group statistics diatas dapat kita ketahui dari data yang dihasilkan oleh kelas eksperiment sebanyak 10 orang memiliki nilai rata-rata 152,70 dan pada kelas control sebanyak 10 orang memiliki nilai rata-rata 124,00 yang telah diperoleh masing-masing kelas. Secara deskreptif statistik dapat kita ambil kesimpulan terdapat perbedaan dari hasil kelas eksperimen dan kelas control. Untuk membuktikan apakah perbedaan tersebut signifikan (nyata) atau tidak maka kita perlu dalam melakukan independent samples test.

Berdasarkan hasil yang diperoleh pada tabel output diatas uji independent samples test hasil belajar santri dapat kita ketahui nilai Sig. (2-tailed) adalah 0,000. Berdasarkan kriteria dalam pengambilan keputusan 0,000 $<0,05$, maka Ho ditolak dan Ha diterima. Sehingga ada pengaruh yang signifikan dalam keefektifan bimbingan kelompok berbasis lalaran dalam mengatasi kcemasan terhadap hafalan kelas sabrowi C Pondok Pesantren Roudlotut Tholibin.

Setelah diberi bimbingan kelompok oleh peneliti tahap selanjutnya yang akan dilakukan adalah memberikannya posttest terhadap 20 santri tersebut berupa metode tes. Metode tes disini berupa pemberian posttest berupa angket yang akan diisi oleh 20 santri kelas eksperimen kelas control. Dari situlah peneliti menilai tingkat kecemasan santri dalam memberikan hafalan yang telah diberikan dengan menggunakan alat ukur SPSS yang telah tersedia.

Berdasarkan kriteria dalam pengambilan keputusan Sig. 0,000 <0,05, maka Ho ditolak dan $\mathrm{Ha}$ diterima. Sehingga ada pengaruh yang signifikan dalam keefektifan bimbingan kelompok berbasis lalaran dalam mengatasi kcemasan terhadap hafalan kelas sabrowi C Pondok Pesantren Roudlotut Tholibin.

Dari hasil tes normality tersebut dapat kita lihat dari nilai Sig. atau signifikasi atau nilai probabilitas memiliki hasil nilai normal. Dari hasil nilai pretest eksperimen, pretest kelas control, posttest eksperimen, posttes kelas control pada Kolmogorov-Smirnov terdapat signifikasi atau nilai probabilitas 0,200 > 0,05 maka hasilnya normal. Dari hasil Shapiro-Wilk pada nilai pretest eksperimen Sig. 0, $148>0,05$, pretest kelas control Sig. 0,107 > 0,05, posttest eksperimen Sig. 0,346>0,05, posttes kelas control Sig. 0,895 >0,05 maka hasilnya normal.

Uji independent samples test hasil belajar santri dapat kita ketahui nilai Sig. (2-tailed) adalah 0,000. Berdasarkan kriteria dalam pengambilan keputusan $0,000<0,05$, maka $\mathrm{Ho}$ ditolak dan $\mathrm{Ha}$ diterima. Maka terdapat pengaruh yang signifikan dalam keefektifan bimbingan kelompok berbasis lalaran dalam mengatasi kcemasan terhadap hafalan kelas sabrowi C Pondok Pesantren Roudlotut Tholibin.

Penelitaian ini didukung oleh Rela Mar'ati dan Moh. Toriqul Chaer dengan judul sekripsi Pengaruh Pembacaan dan Pemaknaan Ayat-Ayat Al-Qur'an terhadap penurunan Kecemasan Pada Santriwati Aliyah di Pondok Pesantren Ar Rohmah Ngawi pada tahun 2014 dalam Hasil rata-rata skor kecemasan kelompok kontrol 24.34 dan kelompok eksperimen 26.66 yang artinya kedua kelompok memiliki ratarata kecemasan yang sama pada tahap pretest yaitu kecemasan tingkat berat. 
Dan penelitian ini dimantapakan lagi oleh Wela Aswida yang berjudul keefektifan bimbingan kelompok dalam mengurangi kecemasan berkomunikasi pada siswa. Berdasarkan data hasil pretest dan posttest tingkat kecemasan berkomunikasi siswa diperoleh nilai Z hitung sebesar -3,185. Sedangkan nilai $Z$ tabel dengan $\alpha=5 \%$ adalah $-1,65$. Berdasarkan data tersebut dapat disimpulkan bahwa $Z$ hitung $>Z$ tabel $(-3,185>-1,65)$, maka Ho ditolak atau terdapat perbedaan yang signifikan pada tingkat kecemasan berkomunikasi siswa sebelum dan sesudah diberikan layanan bimbingan kelompok, dimana tingkat kecemasan berkomunikasi siswa menurun setelah diberikan layanan bimbingan kelompok.

Dalam penelitian ini akan lebih berguna apabila dari peneliti digunakan sebagai usulan perbaikan dalam penelitian. Dalam hal ini agar penelit-peneliti berikutnya dalam melakukan penelitian lebih baik dari peneliti ini. Dari situlah penelitian dapat dipergunakan untuk mengatasi kecemasan dalam menghafal. Didalam penulisan ini penulis sangat menyadari terdapat banyak sekali kesalahan dan kekurangan dalam penelitian baik itu berupa tenaga, pengetahuan, dan waktu dalam melakukan penelitian.

\section{KESIMPULAN}

Dari hasil yang telah diperoleh dalam penelitian bimbingan kelompok berbasis lalaran dapat mengatasi kecemasan terhadap hafalan kelas sabrowi C pondok pesantren roudlotut tholibin 28 purwosari metro utara kota metro. Sehingga penulis menyarankan untuk menggunakan bimbingan kelompok berbasis lalaran untuk mengatasi kecemasan terhadap hafalan pada santri.

\section{DAFTAR PUSTAKA}

Ashari, W., Sugiharto, D. Y. P., \& Supriyo, S. (2016). Pengembangan Model Konseling Kelompok Dengan Teknik Pengelolaan Diri Untuk Meningkatkan Efikasi Diri Siswa Terhadap Perilaku Berisiko Merokok Di Smk Ypt 1 Purbalingga. Jurnal Bimbingan Konseling, 5(2), 126-133.

Astuti, A. (2018). Efektivitas Konseling Behavioral Dengan Teknik Desensitisasi Sistematis Untuk Mengurangi Kecemasan Berkomunikasi Di Depan Umum Pada Peserta Didik Kelas Xii Sman 8 Bandar Lampung Tahun Pelajaran 2018/2019 [PhD Thesis]. UIN Raden Intan Lampung.

Bungin, B. (2005). Metodologi penelitian kuantitatif. Jakarta: Kencana.

Fitriyah, L., Marlina, M., \& Suryani, S. (2019). Pendidikan Literasi pada Pembelajaran Kitab Kuning di Pondok Pesantren Nurul Huda Sukaraja. Titian IImu: Jurnal Ilmiah Multi Sciences, 11(1), 20-30.

Mardalis. (1995). Metode penelitian: Suatu pendekatan proposal. Bumi Aksara.

Masduki, Y. (2018). Implikasi Psikologis Bagi Penghafal Al-Qur'an. Medina-Te: Jurnal Studi Islam, 14(1), 18-35.

Narbuko, C., \& Achmadi, A. (2013). Metodologi penelitian: Memberikan bekal teoretis pada mahasiswa tentang metodologi penelitian seta diharapkan dapat melaksanakan penelitian dengan langkah-langkah yang benar. Bumi Aksara.

Purwanto, E. (2013). Metode Penelitian Kuantitatif. Fakultas IImu Pendidikan Universitas Negeri Semarang.

Suardana, A. A. P. C. P., \& Simarmata, N. (2013). Hubungan antara motivasi belajar dan kecemasan pada siswa kelas VI Sekolah Dasar di Denpasar menjelang Ujian Nasional. Jurnal Psikologi Udayana, 1(1).

Sugiyono, S. (2000). Metodologi Penelitian. CV Alfabeta.

Suhardita, K. (2011). Efektivitas penggunaan teknik permainan dalam bimbingan kelompok untuk meningkatkan percaya diri siswa. Edisi khusus, 8(1), 127.

Zainudin, M. (2016). Penerapan metode menghafal aqidatul awam dalam pembelajaran akidah akhlak untuk memantapkan akidah siswa di MI Attaraqqie Malang [PhD Thesis]. Universitas Islam Negeri Maulana Malik Ibrahim. 